\title{
TEJSZÍV KAMPÁNY
}

\section{MILK HEART CAMPAIGN}

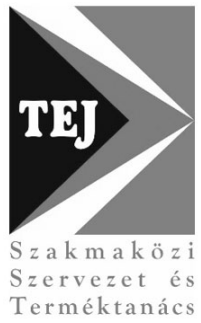

Boglárka Kapás, Tamás Kenderesi (Olmypic swimmers) and Ádám Nagy (national football player) joined the Milk heart campaign in 2017 which is financed by the Milk Interprofessional Organization and Product Board, Community Marketing Fund. This campaign drawed attention to the consumption of domestic dairy products.

DOI: https://doi.org/10.3410o/TEJGAZDASAGvol75iss1pp67-73

\section{A TeJ Szakmaközi Szervezet éS TERMÉKTANÁCS - THE MILK INTERPROFESSIONAL ORGANIZATION AND PRODUCT BOARD}

Az Európai Unió agrárpiaci rendtartásának intézményrendszerében, az ágazatok piacszabályozásában fontos szerepet töltenek be az egyes ágazatokban szerveződő szakmaközi szervezetek.

Az adott tagállam által elismert szakmaközi szervezet egy-egy ágazat adott országban (vagy régióban) működő, különböző vertikális szinten elhelyezkedő szereplőit (termelők, kereskedők és/vagy feldolgozók) fogja össze, azzal az elsődleges céllal, hogy a termékek termelésének (fenntartható termelési módszerek) és forgalmazásának fejlesztését előmozdítsák, valamint elősegítsék a piac szereplői között az információáramlást, és ezzel növeljék a piac átláthatóságát egyfajta ágazati önszabályozást megvalósítva.

Az egyes ágazatok liberalizációs folyamata következményeként csökkent a tagállami és uniós piacszabályozási eszköztár, azonban a Közös Agrárpolitika jelentős szerepet biztosít az egyes ágazatokban megvalósuló, alul- ról szerveződő, nyitott tagság elvén müködő ágazati-szakmaközi önszabályozásnak. Ezt az önszabályozást a szakmaközi szervezetek hivatottak megvalósítani, melyek létrejöttének elősegítése és megerősítése kiemelt fontosságú annak érdekében, hogy az egyes ágazatokban hatékony piacszabályozás múködhessen.

A Tej Szakmaközi Szervezet és Terméktanács létrejötte, múködése és a rajta keresztül megvalósuló ágazati önszabályozó tevékenység megkönnyítheti a magyarországi ágazati érdekegyeztetést, valamint nagyban elősegíti a kormányzat szakmai és jogalkotási tevékenységét. A szakmaközi szervezetünk fóruma az ágazati érdekegyeztetésnek, közelebb hozza egymáshoz a termelőket, a feldolgozókat és a kereskedőket.

A Tej Terméktanács 1992-ben alakult, 2013 óta pedig az agrárügyekért felelős miniszter által elismert, reprezentatív szakmaközi szervezetként fejti ki tevékenységét.

A hazai tejágazaton belül a Tej Szakmaközi Szervezet és Terméktanács az alapanyag-termelés (értékesítés) vonatkozásában 72\%-os, a felvásárolt tej vonatkozásában mintegy 95\%os, míg a (kis)kereskedelem vonatkozásában 70\%-os lefedettséggel rendelkezik. 


\section{ELNÖKSÉG - PRESIDENCY}

Az Elnökség a Tej Terméktanács általános hatáskörü, döntéshozó testülete. Az Elnökség irányítja a Tej Terméktanács tevékenységét a két Küldött Közgyülés közötti időszakban. Tagjait a Küldött Közgyúlés választja meg, három éves határozott időtartamra.

Elnökség létszáma 22 fö, összetétele:

- tejtermelői érdekkör képviseletére 8 fő,

- tejfeldolgozói érdekkör képviseletére 8 fó,

- kereskedői érdekkör képviseletére 4 fö,

- a tejtermelőket, valamint a tejfeldolgozóka tömörítő társult tagok köréből választott 1-1 fö.

\section{KERESKEDELMi és MARKETING BizotTSÁg - COMMISSION OF COMMERCE AND MARKETING}

A Tej Szakmaközi Szervezet és Terméktanács Elnöksége hozta létre a Kereskedelmi és Marketing Bizottságot (továbbiakban Bizottság). A Bizottság tagjai a Terméktanács tag kiskereskedő, valamint tejfeldolgozó vállalatok marketing szakembereiből állnak. A Bizottság kereskedelmi és marketing jellegű feladatokat lát el.

Kereskedelmi jellegü feladatok:

- kereskedelmi szerződések áttekintése, szerződésminták kidolgozása,

- szakmaközi egyeztetés a beszállítók jobb piackiszolgáló képessége érdekében,

- termékfejlesztési/termelési irányok közös meghatározása,

- kereskedelemfejlesztéssel kapcsolatos feladatok elvégzése,

- hazai tejágazat versenyképességének felmérése, javítására vonatkozó javaslatok.

Marketing jellegű feladatok:

- a beszállítók és a kereskedők marketing tevékenységének összehangolása,

- a Terméktanács marketing terveinek, marketing stratégiájának véleményezése,

- vásárokon, kiállításokon történő közösségi részvétel szervezése, értékelése.

\section{Közösségi MARKeting AlaP -}

COMMUNITY MARKETING FUND

A Tej Szakmaközi Szervezet és Terméktanácsnál múködő Közösségi Marketing Alapba történő befizetésról szóló piacszervezési intézkedés kiterjesztéséről szóló 2/2015. (II. 6.) FM rendelet 2. § (1) értelmében a Tej Terméktanács Közösségi Marketing Alapot múködtet, melynek célja, a fogyasztók több, gyakoribb és tudatosabb tej és tejtermék fogyasztásra való ösztönzése, a gyermekek, a fiatalok tej és tejtermék fogyasztásra motiváló nevelésének támogatása, segítségnyújtás az egészségtudatos táplálkozás kialakításában, a tej és tejtermékek fogyasztásának megszerettetésével, valamint a tejtermékek sokféleségének és egészséges táplálkozásban betöltött szerepének bemutatásával. A Közösségi Marketing Alapból kizárólag egységesen valamennyi tej és tejtermék nem márka specifikus közösségi marketingje finanszírozható.

A Terméktanács fent hivatkozott célok elérése, valamint annak érdekében, hogy a 2/2015 (II. 6.) FM rendelet alapján rendelkezésére álló keretösszeg minél hatékonyabb felhasználását lehetővé tegye, 2016. év őszén meghívásos tendert írt ki a Terméktanács középtávú tejmarketing stratégiájának kidolgozására.

A Terméktanács célja a tender során egy olyan program kialakítása volt, amely - összhangban a 2/2015. (II.6.) FM rendeletben foglalt célokkal - lehetővé teszi a tej és tejtermék fogyasztási kultúra formálását, a tej iránti fogyasztói lojalitás erősítését, a Tej Terméktanács tulajdonában lévő Tej- és Sajtszív védjegycsalád ismertségének növelését.

A Közösségi Marketing Alap bevételeit és kiadásait az 1. táblázat foglalja össze.

$\mathrm{Az}$ 1. ábra a Tej Szakmaközi Szervezet és Terméktanács által felügyelt Tejszív Védjegycsaládot szemlélteti. 
A Közösségi Marketing Alap bevételei és kiadásai, HUF (Revenues and Expenditures of the Community Marketing Fund, HUF)

\begin{tabular}{|c|c|c|c|}
\hline Megnevezés (Appellation) & 2015 & 2016 & $\mathbf{2 0 1 7}$ \\
\hline $\begin{array}{l}\text { Piacszervezési hozzájárulás bevétel } \\
\text { (o,o005\%) } \\
\text { (Market organization contribution } \\
\text { revenues (o,0005\%)) }\end{array}$ & 69914539 & 82264181 & 78641085 \\
\hline Védjegy bevétel (Trademark revenues) & 102660624 & 79540100 & 90208100 \\
\hline Egyéb bevétel (Other revenues) & 4000000 & 3281250 & 1000000 \\
\hline Összes bevétel (Total revenues) & 176575163 & 165085531 & 169849185 \\
\hline $\begin{array}{l}\text { Marketing kiadások } \\
\text { (Marketing expenditures) }\end{array}$ & 120276376 & 56210114 & 308763438 \\
\hline $\begin{array}{l}\text { December 31-i egyenleg } \\
\text { (Balance on 31. December) }\end{array}$ & 56298787 & 165214204 & 26299951 \\
\hline
\end{tabular}

Forrás (Source): Tej Szakmaközi Szervezet és Terméktanács (Milk Interprofessional Organization and Product Board)
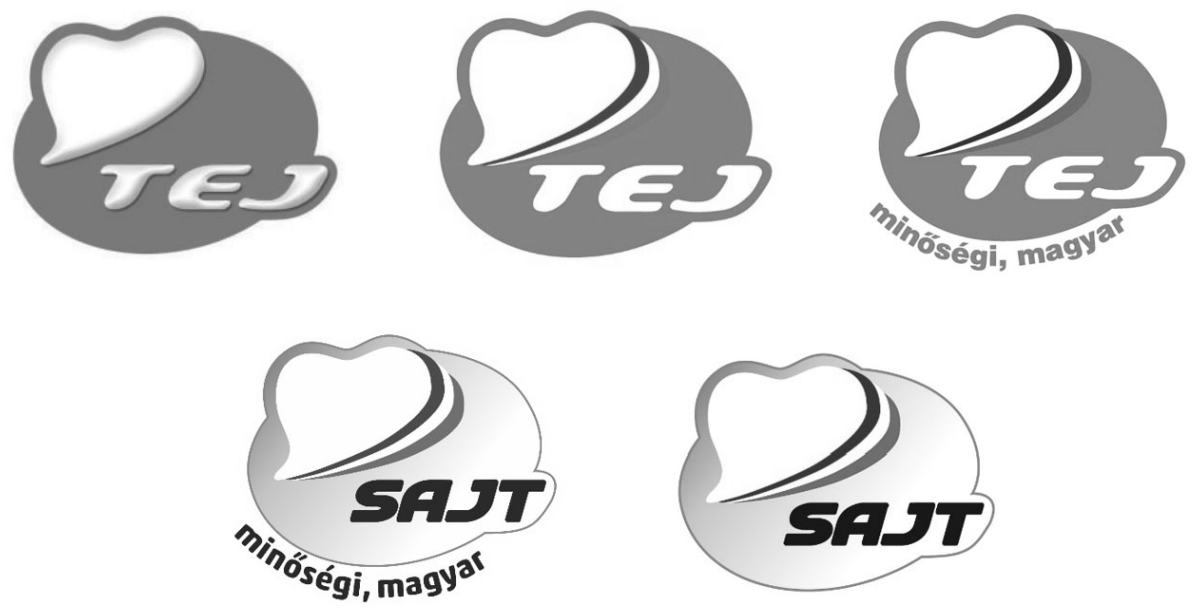

1. ÁBRA

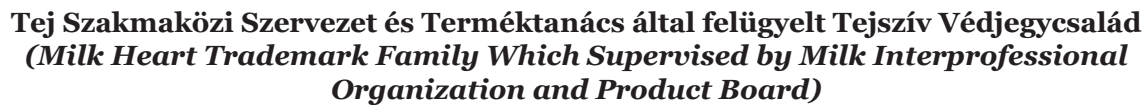

FIG. 1 Organization and Product Board)

Forrás (Source): Tej Szakmaközi Szervezet és Terméktanács (Milk Interprofessional Organization and Product Board) 


\section{TEJSZÍv KAMPÁNY 2017 -}

Milk Heart CAMPaign 2017

A Terméktanács Kereskedelmi és Marketing Bizottsága 2016 őszén két körös meghallgatást követően nyolc ügynökség közül választotta ki a Hinora Global Marketing Kft. által javasolt programot és 2016. december 19-én, hivatalosan elfogadta a 2017-es évre és az azt követő egy évre vonatkozó marketingkommunikációs költségvetést és stratégiát.

Az elfogadott koncepció szerint, a Tej Terméktanács 2017. évi közösségi marketing kampányát fiatal olimpikonok és sportoló példaképek - Kapás Boglárka (1. kép) bronzérmes olimpikon úszónő, Kenderesi Tamás (2. kép) olimpiai bronzérmes úszó és Nagy Ádám (3. kép) válogatott labdarúgó - mint a „tej nagykövetei” támogatták. A Tej Terméktanács kampánya egy integrált kampány volt, visual elemeivel és üzenetével számos kommunikációs csatornán találkozhatott a fogyasztó, többek között televíziós spotok formájában, social media felületeken, outdoor hirdetéseken, valamint online és print megjelenéseken is.

A kampányt megelőzően a Terméktanács kutatást végeztetett a TNS-Hoffmann Piackutató intézettel, melynek során - az általános fogyasztói attitűd kutatás mellett - vizsgálat alá került, hogy a megkérdezettek mely hazai sportolókat találják a leginkább hitelesnek a téma képviseletére. Az eredmények alapján egyértelműen kiderült, hogy a szerződött három sportolót mind teljesítményük, mind személyiségük és hitelességük alapján a „tej ügy” képviseletére a leginkább alkalmasnak találták a válaszadók.

A Tej Terméktanács korábbi kampányaitól eltérően a 2017. évi marketing stratégia alapvető eleme az erőteljes ATL kommunikáció volt. A sportolók részvételével forgatott TV spot, egy impulzív képi és hangi világgal dolgozott, ami azért volt fontos, hogy sikerüljön kitünni a rendkívül erős reklámzajból, fontos cél volt, hogy érzelmi reakciókat váltson ki a célközönségből, akik tudnak azonosulni a sportolók kiemelkedő teljesítményével, életformájával, mindazzal az életstílussal, amit ők képviselnek. A reklámfilm 2017. április 10-től május 31-ig volt látható az AT Média csatornáin. A kampányidőszakra a Terméktanács 1615 GRP-t vásárolt, 30 másodperces spot hosszal, 18-59 éves felnőtt célcsoportban.

A kampány egyik központi eleme volt az országos közterületi megjelenés. A közterületi kampány 2017 májusában - párhuzamosan a televíziós reklámkampánnyal - futott, azt támogatta. Az óriásplakátokon a reklámspotban megjelenő fiatal olimpikonok, a Tejszív logó, valamint a kampány szlogenje kerültek megjelenítésre.

A kampány során nagy hangsúly került arra, hogy a kampányüzenet, valamint a Tejszív logó a lehető legtöbb és legváltozatosabb felületen megjelenítésre kerüljön, a lehető leghatékonyabban elérve ezáltal a fogyasztókat. E cél érdekében a kampány visual elemeivel támogatott hirdetések kerültek elhelyezésre számos áruházlánc akciósújságjaiban.

A kampány valamennyi eleméhez szorosan kapcsolódik az online kommunikáció, melynek érdekében a Terméktanács a www.tejsziv.hu weboldal átalakítását, a kampány arculatához igazítását tűzte ki célul. A megújuló weboldalon - mely weboldal a kampány során valamennyi kommunikációs felületen megjelent, illetve a fogyasztókat nyereményjátékokkal a webhelyre irányította - feltüntetésre kerültnek a forgalomban lévő „Tejszív” és „Sajtszív” logós termékek is.

A kampány kommunikációja intenzív PPC támogatással a közösségi média oldalakon is aktívan zajlott. www.facebook.hu/tejsziv, www.instagram.com/tejsziv

A 2017. évi marketing kampány fóbb aktivitásai és időbeni alakulásuk az alábbiak szerint történt:

1. televíziós reklámfilm (április-május)

2. youtube film terjesztés támogatással (április-május)

3. közterületi megjelenés (május)

4. tejsziv.hu fejlesztés és üzemeltetés (április-december)

5. online média (május-december)

6. Facebook/Instagram tartalomgyártás PPC támogatással (április-december)

7. PR aktivitások (május-december)

8. akciósújság hirdetések (május-július) 


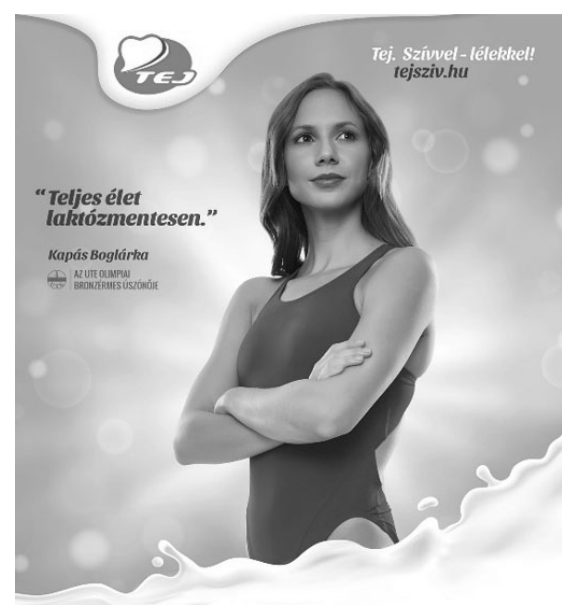

A bajnokolkban Tejszív dobog. És Benned?

Keresd a Tejszívvel ellátott terméheket! (t)

1. KÉP PIC. 1

Kapás Boglárka - bronzérmes olimpi-

kon úszónő (Boglárka Kapás Bronze Medalist Olympic Swimmer)

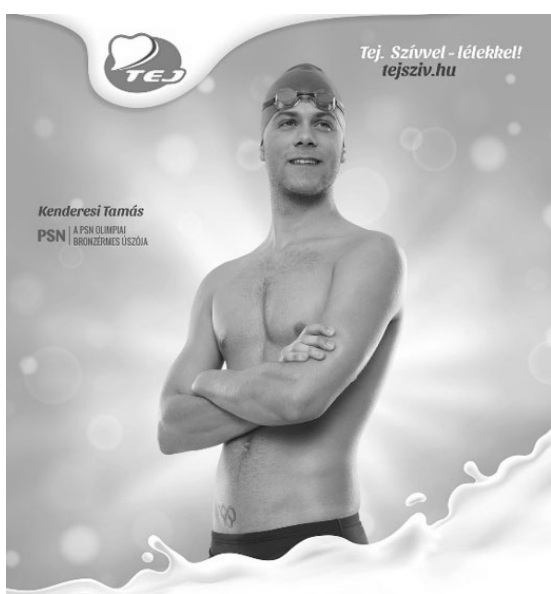

\section{A bajnokokban} Tejszív dobog. És Benned?

Keresd a Tejszívvel ellátott termékeket! Pes

2. Kर्EP PIC. 2

Kenderesi Tamás - bronzérmes olimpikon úszó (Tamás Kenderesi Bronze Medalist Olympic Swimmer)

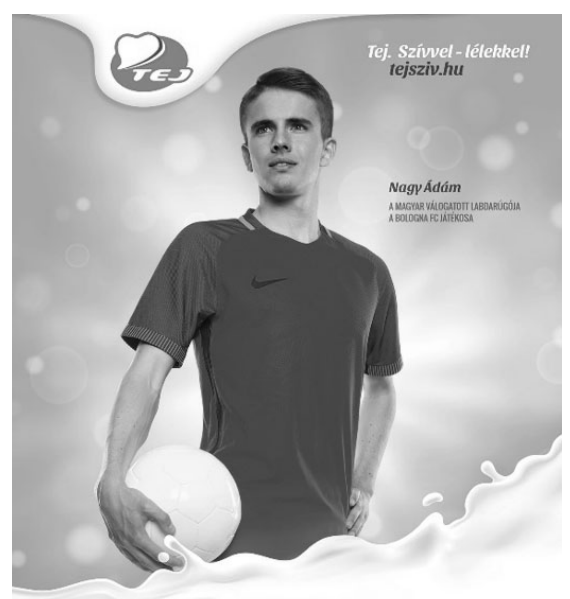

\section{A bajnokokban Tejszív dobog. Es Benned?}

Keresd a Tejszívvel ellátott termékeket! 2

3. KÉP PIC. 3

Nagy Ádám - válogatott labdarúgó (Ádám Nagy National Football Player) 


\section{TEJKAMION ROADSHOW -}

\section{Milk CAMiON RoAdshow}

A Tej Szakmaközi Szervezet és Terméktanács felismerve a fiatalok általában helytelen fogyasztói szokásait, tizenöt éve elkezdte, és folyamatosan megszervezte az iskolai edukációs programot.

A Terméktanács szervezésében 2017. őszén kezdetét vette a „Tej útja” elnevezésű Roadshow, melynek során az egyedülálló, kifejezetten a gyermekek részére edukációs céllal kialakított Tejkamion (4. kép) járta az országot és 51 általános iskolában, valamint 20 áruházláncban és 12 rendezvényen, összesen 83 állomáson népszerüsítette a hazai tejet és tejtermék fogyasztást.

A program újszerú, modern technikai kivitelezése miatt rendkívül népszerü volt a diákok körében, élménypontként funkcionált az iskolákban. A roadshow során az érdeklődő gyermekek öt különböző élményállomáson vehettek részt, melyek segítségével végig járhatták a tej útját tehéntől a boltok polcaiig. A gyerekeknek lehetőségük volt a Tejkamion interaktív, látványos programjainak kipróbálására, valamint a kamiont kísérő dietetikus segítségével edukációra épülő, izgalmas előadással és érdekes játékokkal tette a Terméktanács még élvezetesebbé a tanulást.

A 2017 szeptember 1-december 19 között lezajlott iskolai edukáció keretében mintegy 9000 általános iskolás gyermek volt részese a programnak, a kereskedelmi egységek parkolóiban a hétvégi napokon pedig további 5 000-10 ooo látogató járhatta végig a „Tej útját”.

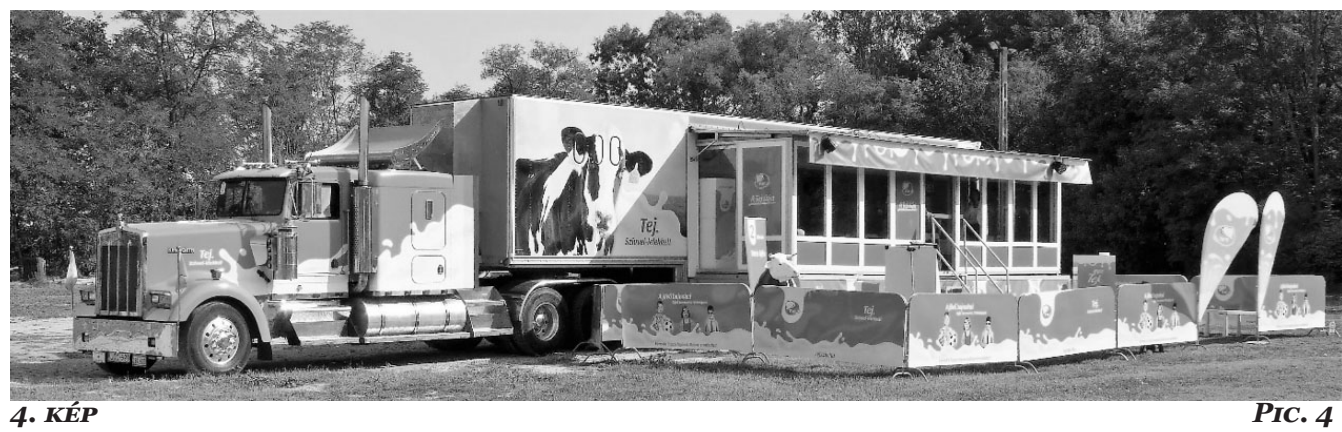

Tejkamion (Milk Camion)

\section{OrSZÁgos Mezógazdas ÁGI ÉS ÉLELMISZERIPARI KIÁLLÍTÁS ÉS VÁSÁr (OMÉK) - \\ NATIONAL AGRICULTURE AND FoOD EXHIBITION AND FAIR}

A Tej Szakmaközi Szervezet és Terméktanács 2017. évben ismét kiállítóként vett részt Magyarország legnagyobb múltú mezőgazdasági seregszemléjén, a 78. OMÉK-on. A több mint 90 ooo látogatót számláló OMÉK-on egy olyan stand kialakítása volt a cél, amely egyszerre edukál, a látogatók aktív részvételét lehetővé teszi és szórakoztat. Ennek megfelelően a látogatók gyakorlatilag ,játszva szórakozhattak” a Tej Terméktanács kiállítási területén.

A koncepció szerint a stand látogatói a kiál- lítási területen végigjárhatták a tej útját, illetve annak különböző állomásait (termelés, feldolgozás, kereskedelem). A látogatókat (jellemzően a fiatal generációt) a stand bejárása során különböző érdekes feladatok és szórakoztató élményállomások várták. A Terméktanács célja az volt, hogy a látogatók - mire a tej útjának végére érnek - nemcsak számos érdekes információt tudjanak meg a tejről, hanem egyúttal élményekkel gazdagodva járhassák be a stand teljes területét.

A 260 négyzetméteres stand központi elemét képezte a „Tejkamion”, mely monumentális és látványos megjelenésével valamennyi látogató számára élményt nyújtott.

A stand interaktív vetélkedőjét, „a tej útját” legalább 4000 fő járta végig. A látogatók és az érdeklődök száma azonban ennek többszöröse 
volt. A kiállítás egyik leglátogatottabb napján, szombaton, a Tejnagykövet, Kapás Boglárka, olimpikon úszónő dedikálással és fotózással egybekötött közönségtalálkozón vett rész a Terméktanács standján. Szintén ezen a napon az ALMA együttes gyermekkoncertje került megrendezése a stand erre a célra kialakított színpadán.

A Tej Terméktanács ingyenes megjelenési lehetőséget biztosított a KKASE-Sajtkészítők Egyesület tagjainak megjelenítésére. A standon egy közel 20 nm-es területet, az Egyesület arculatának és igényeinek megfelelően került kialakításra, lehetőséget biztosítva az Egyesület sajtkészítő bemutatóinak lebonyolításához, valamint a vajköpülő közösségi attrakció megtartásához.

A vásár záróünnepségén sor került az OMÉK Közönségdíjának átadására, melyet minden évben az a kiállító nyer el, aki a látogatóktól a legtöbb szavazatot kapja. Idén a Tej Terméktanácsnak szavazták meg ezt a rangos jelölést.

\section{8. ÉVI TERVEK - PlaNS IN 2018}

Tekintettel arra, hogy a Tej Szakmaközi Szervezet és Terméktanácsnál múködő Közösségi Marketing Alapba történő befizetésről szóló piacszervezési intézkedés kiterjesztéséről szóló 2/2015. (II. 6.) FM rendelet további három évvel, 2020. december 31-ig meghosszabbításra került, 2018. január elején megkezdődött a munka a Tej Terméktanács Közösségi Marketing Alapjának felhasználására vonatkozó, a hazai tejfogyasztás népszerüsítését célzó 2018. évi tejmarketing stratégia és marketing terv kidolgozására és végrehajtására.

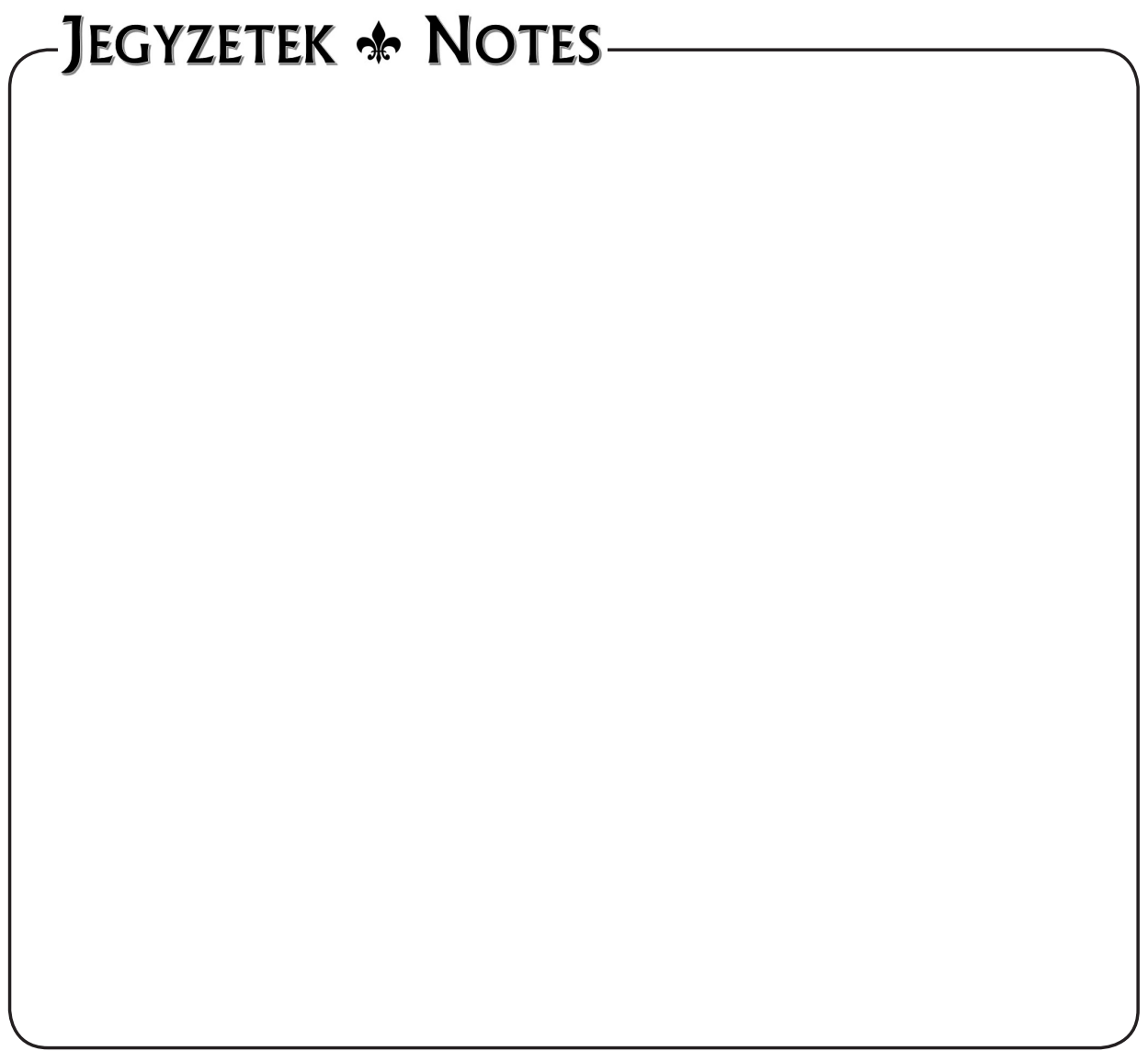

